\title{
Selected Caddo Ceramic Artifacts from the E. H. Buchanan Plantation (41RR5), Bowie County, Texas
}

Timothy K. Perttula

Heritage Research Center, Stephen F. Austin State University

Follow this and additional works at: https://scholarworks.sfasu.edu/ita

Part of the American Material Culture Commons, Archaeological Anthropology Commons, Environmental Studies Commons, Other American Studies Commons, Other Arts and Humanities Commons, Other History of Art, Architecture, and Archaeology Commons, and the United States History Commons

Tell us how this article helped you.

This Article is brought to you for free and open access by the Center for Regional Heritage Research at SFA ScholarWorks. It has been accepted for inclusion in Index of Texas Archaeology: Open Access Gray Literature from the Lone Star State by an authorized editor of SFA ScholarWorks. For more information, please contact cdsscholarworks@sfasu.edu. 
Selected Caddo Ceramic Artifacts from the E. H. Buchanan Plantation (41RR5), Bowie County, Texas

\section{Creative Commons License}

\section{(c) (1) \&}

This work is licensed under a Creative Commons Attribution-NonCommercial 4.0 International License 


\title{
Selected Caddo Ceramic Artifacts from the E. H. Buchanan Plantation (41RR5), Bowie County, Texas
}

\author{
Timothy K. Perttula
}

\section{Introduction}

The E. H. Buchanan site is an ancestral Caddo settlement investigated by B. B. Gardner of The University of Texas in July 1930. The site lies between Pond Creek and Salt Well Slough, streams that drain into the nearby Red River, and they are not far upstream from the large Caddo mound and village center at the Sam Kaufman site (41RR16) (see Skinner et al. 1969; Perttula 2008a) (Figure 1) on Mound Prairie.

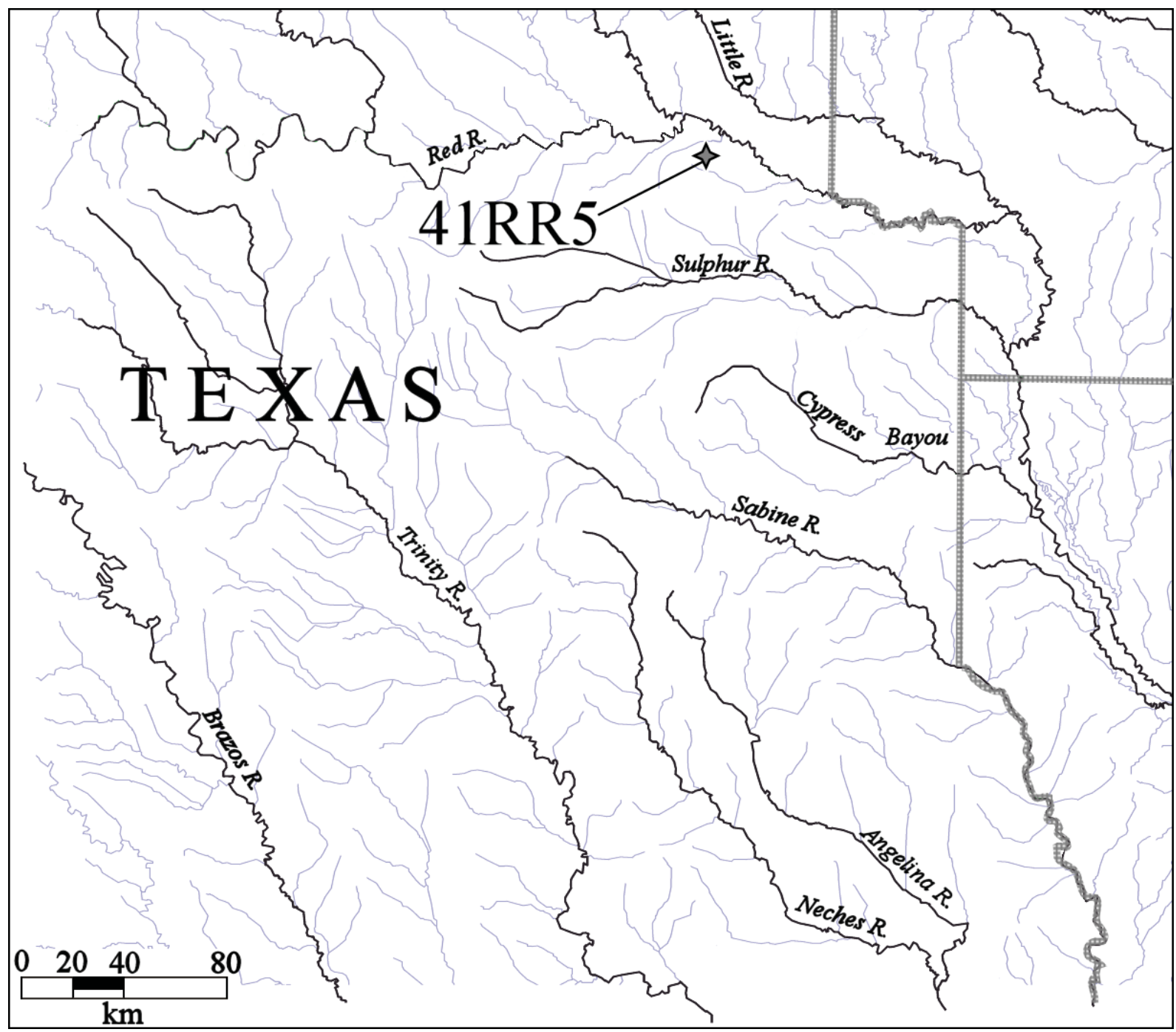

Figure 1. Location of the E. H. Buchanan Plantation site (41BW5) in East Texas. 
As described in Gardner's notes on file at the Texas Archeological Research Laboratory (TARL) at The University of Texas at Austin, the site lay adjacent to a salt lick on "Buchanan's upper place," on a natural alluvial mound. The archaeological deposit was ca. 20-25 cm thick, with much charcoal and ash. Furthermore, Gardner noted that "there is a spot comprising approximately $1 / 2$ acre on which are literally bushels of potsherds, apparently from very large vessels. Unlike most of such places, it is on heavy, stiff soil." The description provided by Gardner strongly suggests that the E. H. Buchanan Plantation is another salt-making site near Salt Well Slough, much like the Salt Well Slough site (41RR204) (Kenmotsu 2005), 41RR248, 41RR256, and 41RR257 (Perttula 2008b).

\section{Selected Artifacts from the E. H. Buchanan Plantation Site (41RR5)}

Artifacts present in the collection include five deer ulna awl fragments, one dark gray chert side scraper, a reddish-dark gray chert drill/perforator, and a dark gray chert bilateral expedient flake tool. There are also two notable ceramic artifacts in the collections from the site held by TARL: a decorated spindle whorl and an engraved ear spool.

Both of these ceramic artifacts are made from a shelltempered clay; shell-tempered pottery sherds are characteristic of post-A.D. 1300 McCurtain phase salt-making sites in the Salt Well Slough area (see Kenmotsu 2005). The spindle whorl has a central drilled hole that is $8.1 \mathrm{~mm}$ in diameter, and the spindle whorl itself is $45.5 \mathrm{~mm}$ in diameter and $6.4 \mathrm{~mm}$ thick. One face of the spindle has a series of six broad incised or trailed lines that radiate out from the drilled central hole (Figure 2). The other face of the spindle whorl is plain.

The shell-tempered ear spool is $17.2 \mathrm{~mm}$ in height, and its outer circular face is $21.9 \mathrm{~mm}$ in diameter. The outer face has been decorated with two concentric circular engraved lines (Figure 3). The back end of the ear spool is $16.8 \mathrm{~mm}$ in diameter.

\section{Summary and Conclusions}

Investigations by B. B. Gardner of the University of Texas in 1930 at the E. H. Buchanan Plantation site (41RR5) suggest that it is one of the several other known ancestral Caddo saltmaking sites of Late Caddo period age on Salt Well Slough in the Mound Prairie area along the Red River. In his work he recovered an assortment of bone and stone tools, as well as two distinctive shell-tempered ceramic artifacts (described in detail herein, see Figures 2 and 3) that are apparently part of the material culture assemblage of Caddo salt-makers: an incised/trailed spindle whorl and an engraved ear spool.

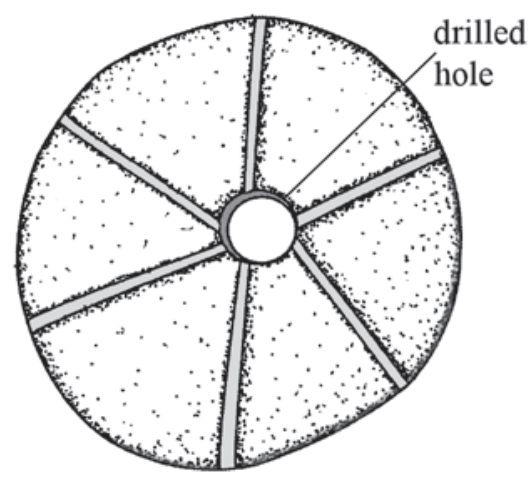

Figure 2. Spindle whorl sherd from the E. H. Buchanan Plantation site (41RR5).

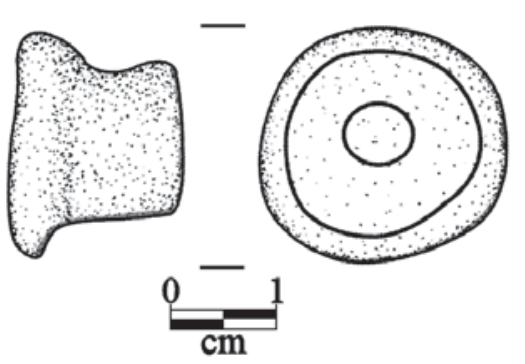

Figure 3. The shell-tempered ear spool from the E. H. Buchanan Plantation (41RR5). 


\section{Acknowledgments}

Thanks to Marybeth Tomka at TARL for facilitating access to the E. H. Buchanan Plantation site collections. Lance Trask prepared the figures in this article.

\section{References Cited}

Kenmotsu, N. A.

2005 Investigations at the Salt Well Slough Site (41RR204), a Salt Making Site in Red River County, Texas. Archeological Reports Series, No. 4. Texas Historical Commission, Austin.

Perttula, T. K.

2008a The Archeology of the Roitsch Site (41RR16), an Early to Historic Caddo Period Village on the Red River in Northeast Texas. In Collected Papers from Past East Texas Archeological Society Summer Field Schools, edited by T. K. Perttula, pp. 313-628. Special Publication No. 5. Texas Archeological Society, San Antonio.

2008b Archeological Survey of the Roitsch Farm and Adjoining Lands, 1991 and 1992 Texas Archeological Society Field School, Red River County, Texas. In Collected Papers from Past Texas Archeological Society Summer Field Schools, edited by T. K. Perttula, pp. 173-312. Special Publication No. 5. Texas Archeological Society, San Antonio.

Skinner, S. A., R. K. Harris, and K. M. Anderson (editors)

1969 Archaeological Investigations at the Sam Kaufman Site, Red River County, Texas. Contributions in Anthropology No. 5. Department of Anthropology, Southern Methodist University, Dallas. 